\title{
Uma Neocristandade no Brasil: a atuação do Cardeal Leme para tornar o Brasil um país Católico
}

\author{
Orientador: Luís Corrêa Lima
}

Doutorando: André Phillipe Pereira

Área de Concentração: Teologia Sistemático-Pastoral

Linha de Pesquisa: Religião e Modernidade

Projeto de Pesquisa: História da Igreja e Modernidade: Permanências e Mudanças

A neocristandade no Brasil foi uma tentativa de restaurar o catolicismo no Brasil, em plena continuidade com a Igreja Universal. Este trabalho analisa a atuação do segundo Cardeal brasileiro Dom Sebastião Leme da Silveira Cintra e sua contribuição no processo de neocristandade na Igreja Católica do Brasil entre os anos de 1920-1940. Dom Leme exerceu enorme influência na Igreja do Brasil, usando da cultura, dos meios de comunicação, da aproximação com o Governo, da arregimentação das massas e dos intelectuais neste processo. Foi o mais expressivo episcopado, no país, na tentativa de revitalizar os valores e o sentido do catolicismo na sociedade brasileira moderna. Por meio de um programa em plena união com a Igreja Universal, esse Cardeal deu passos profundos em vários campos da sociedade, buscando implantar e reformar o espírito católico. Para tanto, da implementou leis e práticas religiosas, aumentando e incentivando, sobretudo, as devoções a eucaristia, ao Sagrado Coração de Jesus, a Nossa senhora e o amor e obediência ao Papa. Observa-se o conceito de neocristandade como chave de compreensão do catolicismo moderno e das discussões em torno da modernidade. Discute-se o entendimento do conceito com base no pontificado do Papa Leão XIII, porém aprofundando com os pontificados de Pio X, Bento XV e Pio XI. A neocristandade no Brasil é compreendida, portanto, a partir das características apresentadas pela Igreja Romana e trazida para a realidade brasileira. A pesquisa apoia-se numa ampla bibliografia, nas atas de visitas pastorais, comunicados e 
avisos diocesanos, artigos publicados em relação ao tema, pesquisa em documentos nos arquivos das Arquidioceses de Curitiba, São Paulo e sobretudo do Rio de Janeiro. Focaliza-se neste trabalho a relação Igreja Estado, no período proposto, e a relação da hierarquia eclesiástica com os fiéis leigos e o empenho de uma elite intelectual para instaurar uma neocristandade no Brasil.

Palavras-chave: Neocristandade. Dom Leme. Igreja Romana. 